\title{
SUSTAINABILITY IN ENGINEERING DESIGN
}

\author{
Amy C. Hsiao \\ Faculty of Sustainable Design Engineering, University of Prince Edward Island \\ ahsiao@upei.ca
}

\begin{abstract}
The concepts, issues, and themes surrounding the definition of sustainability is discussed in this paper, as it is presented in a first year undergraduate engineering course called "Sustainability in Engineering Design" at the University of Prince Edward Island. Students incorporate, reflect upon, and analyze many examples and aspects of sustainability. Students are introduced to practical frameworks which they use to formulate their own definition of what sustainability means in engineering design. Students work in teams to analyze and articulate the impact that technological innovation and engineering design has on sustainability. As a result, an understanding of sustainability is established such that students are able to design for, articulate, quantify, and lead with a "sustainability mindset". The topics in the course "Sustainability in Engineering Design" are built upon in subsequent, advanced courses in manufacturing, robotics, renewable energy systems, and bioresources. As such, this work discusses the perspective of the future engineer as a global citizen, critical thinker, and problem solver who is able to consider the social, economic, environmental, cultural factors, and their inter-relationships, contributing to the understanding of sustainability in the engineering design process.
\end{abstract}

Keywords: sustainability mindset, engineering design, materials life cycle, energy security, zero waste, environmental impact

\section{INTRODUCTION}

The engineering profession is responding to the call to address the climate change crisis, recognizing however that sustainable engineering is not only in "protecting the environment". Sustainable engineering requires a new mindset, a revised approach in future engineers when addressing solutions and creating new innovations for improved quality of life, improved quality of work, human development and equality, and a green, energysecure future. According to Engineers Canada's National Guideline on Sustainable Development and Environmental Stewardship for Professional Engineers [1], the definition of sustainability is "the ability to meet the needs of the present without compromising the ability of future generations to meet their own needs, through the balanced application of integrated planning and the combination of environmental, social, and economic decision-making processes". As such, the question is presented of how this definition can be introduced to firstyear engineering students and developed into a mindset that will prevail in their approach to engineering design and technical problem solving in the future. A starting point was to probe the students' understanding of what engineers do and ask them what they know of the term "sustainability". From that, topics were explored via classroom discussions, hands-on lab sessions, team projects called "living labs", and online reflection assignments. The course set four learning outcomes that were matched to Canadian Engineering Accreditation Board (CEAB) Graduate Attributes (GA), as shown in Table 1. The main GA that is developed in this course is GA09: Impact on Engineering on Society and Environment, with others being introduced, such as GA12: Life-long learning, GA08: Ethics and Equity, and GA03: Investigations of Complex Problems.

Table 1: Learning Objectives for "Sustainability in Engineering Design".

\begin{tabular}{|c|c|c|}
\hline \multicolumn{2}{|c|}{ Learning Objectives (LOs) } & $\begin{array}{l}\text { CEAB } \\
\text { Graduate } \\
\text { Attributes } \\
\text { (GAs) }\end{array}$ \\
\hline LO \# 1 & $\begin{array}{l}\text { Define what sustainability } \\
\text { means in engineering design. }\end{array}$ & $\begin{array}{l}\text { GA09, } \\
\text { GA12 }\end{array}$ \\
\hline LO \# 2 & $\begin{array}{l}\text { Model and implement total } \\
\text { life materials cycles when } \\
\text { developing products and } \\
\text { processes. }\end{array}$ & $\begin{array}{l}\text { GA01 to } \\
\text { GA05 }\end{array}$ \\
\hline LO \# 3 & $\begin{array}{l}\text { Consider the social, economic, } \\
\text { environmental, and cultural } \\
\text { factors, and their inter- } \\
\text { relationships, contributing to } \\
\text { the general understanding of } \\
\text { Sustainability. }\end{array}$ & $\begin{array}{l}\text { GA09, } \\
\text { GA11, } \\
\text { GA12 }\end{array}$ \\
\hline LO \# 4 & $\begin{array}{l}\text { Work as a team to analyze and } \\
\text { communicate the impact } \\
\text { technological innovation and } \\
\text { engineering design has on } \\
\text { sustainability. }\end{array}$ & $\begin{array}{l}\text { GA06, } \\
\text { GA07, } \\
\text { GA09 }\end{array}$ \\
\hline
\end{tabular}




\begin{tabular}{|l|l|l|}
\hline \multicolumn{2}{|c|}{ Learning Objectives (LOs) } & $\begin{array}{l}\text { CEAB } \\
\text { Graduate } \\
\text { Attributes } \\
\text { (GAs) }\end{array}$ \\
\hline LO \#5 & $\begin{array}{l}\text { Reflect on the individual's } \\
\text { impact as a global citizen and } \\
\text { sustainable design engineering } \\
\text { student. }\end{array}$ & $\begin{array}{l}\text { GA08 to } \\
\text { GA10, } \\
\text { GA12 }\end{array}$ \\
\hline CEAB List of Graduate Attributes: \\
1. & Knowledge base in engineering \\
2. & Problem analysis \\
3. & Investigations of complex problems \\
4. & Design \\
5. & Use of engineering tools \\
6. & Individual and team work \\
7. & Communications skills \\
8. & Professionalism \\
9. & Impact of engineering on society and \\
environment & \\
10. & Ethics and equity \\
11. & Economics and project management \\
12. & Life-long learning \\
\hline
\end{tabular}

\section{DEVELOPING A SUSTAINABILITY MINDSET}

\subsection{As A Global Citizen}

The topic of "climate change" was the first to be explore in the course, as the students indicated some knowledge of the phrase from news, social, and public media. Climate change, as seen through video clips of the documentary "An Inconvenient Truth," was shown in the classroom [1]. Its content and its narrator's motivation to call others to environmental stewardship and global warming served as initial ideas to help students form, revise, or improve their working definition of sustainability.

This topic led into the second topic of "single-use plastics", another phrase that is easily recognized by students and is interrelated to the topic of "preservation of the oceans and wildlife". Several videos, e.g. from National Geographic, CNN [2], and the World Economic Forum, were shown in class. These videos were followed by facilitated discussions on what sustainability means and what students think being a global citizen means.

The course also brought forth and integrated the principles expressed in the Canadian Charter of Rights and Freedoms, the Universal Declaration of Human Rights adopted by the United Nations General Assembly in 1949, and the Engineers Canada Code of Ethics for Professional Engineers through classroom discussions and weekly assignments. Additionally, the questions often posed at the start of the engineering design process, e.g. "what is the problem we are addressing?" and "what are potential solutions that may address the actual problem?", are considered from a personal (i.e. how does it affect the person/persons), societal (what role does community have), and technological point of view.

\subsection{Philosophy of Technology}

Sustainability as a shared bridge between being a global citizen and a future engineer was also explored in the context of the "philosophy of technology", as it relates to knowledge, experience, identity, reality, truth, and existence. Classroom discussion primarily focused on technology and self, in which a TedTalk called "Connected, but alone?" challenged the use and role of technology for self-reflection, accessibility, connection, conversation, human intimacy and empathy [3].

\subsection{As a Future Engineer}

The popular topic of "buying local" was used to transition between the identity of a student as both, a global citizen and a future engineer, for developing a sustainability mindset. As Charlottetown has a vibrant Farmers' Market and several community supported agriculture (CSA) initiatives, the "farm-to-table" concept is endeared and understood. In addition, Prince Edward Island is resplendent with agricultural enterprises, e.g. farming, fishing, dairy, and livestock. The products of these agricultural ventures are marketed, in demand, and sold successfully around the world and shipped internationally, such that students connect with this topic from a local perspective. Building upon this, the case study of Whole Foods' motivation to "buy local" is presented as an example of sustainable supply chain management, and students begin to realize the depth and breadth of how engineering applies, affects, and overlaps with their lifestyles [4]. The case of Nestlé integrating company practice into the social and cultural context of the dairy district in India, as presented by Porter and Kramer [5], draws on similarities between PEI and another part of the world and encourages further integration of the student's beliefs, values, and goals into a mindset for sustainable development. The case of Blackberry partnering with Chinese manufacturers also demonstrates the global nature of international strategies for technology innovation [6].

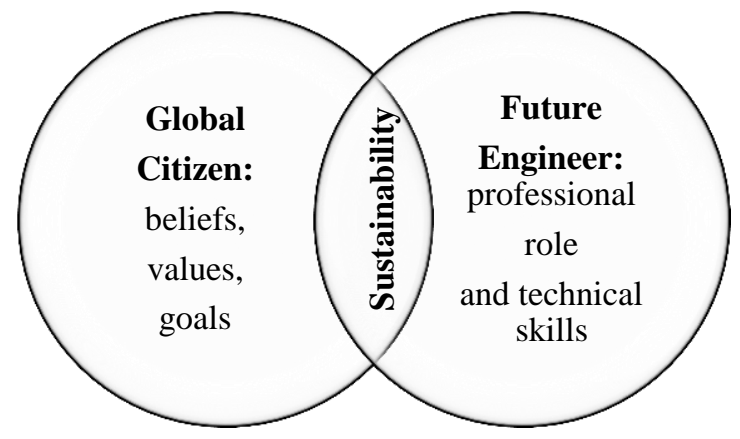

Fig. 1. The relationship between personal self and professional self that develops a sustainability mindset. 


\subsection{Energy and Electricity}

In this introductory course, Canada's role in energy generation and energy consumption is examined in comparison with the United States and in an international context [7]. Students learn the basic definitions of energy forms, types, and sources. Students learn that the United States' energy consumption is primarily from petroleum sources and Canada's major sources of electricity are renewable and non-greenhouse-gas (GHG) emission sources, in comparison. Students learn about electricity costs per province and engage in direct-impact calculations of costs and energy savings, e.g. when they replace all of their household incandescent light bulbs with light-emitting diode (LED) light bulbs. In addition, students are introduced to concepts such as:

- Energy services

- The energy ladder

- Energy intensity

- Derived demand

- Energy poverty

- Energy social costs

- Distributed energy systems

- Energy security

That is, when incomes are low, only the most critical energy needs of the home are met, using fuels and energy sources that are typically polluting and harmful to human health. When households climb the "energy ladder", they benefit from a wider variety of energy services, they transition to higher density fuels and increase their overall energy consumption. A country that has an economy based on subsistence agriculture will require less energy for its economic production than an industrialized nation producing steel, chemicals, and manufactured goods. When societies industrialize, their energy intensity goes up; however, when a large proportion of households lack access to the formal energy sector, energy poverty means these households are unable to access or afford commercially provided energy and must rely on the social costs of gathered biomass or on limited purchases of kerosene, charcoal and batteries to sustain their homes.

Students are also introduced to the idea of distributed energy, by which energy generation is located on or near the sites in which it will be used, and this generally produces energy at much smaller scales and intensities compared with conventional energy systems. Distributed energy can be a stand-alone system at a single site, or they can be connected into a system. Distributed energy systems allow the use of intermittent renewable energy more effectively that a large centralized power system might be able to, and they help to diversify energy resources. In the context of classroom discussion, many of these energy concepts and terms are illustrated by firsthand experiences and knowledge as shared by the diversity of our students, guest speakers, and the professor, of which an example is shown in Fig. 2. Fig. 2 shows a man at sunset near the Great Wall of China sourcing a large log and carrying it home on a gasolinepowered scooter.

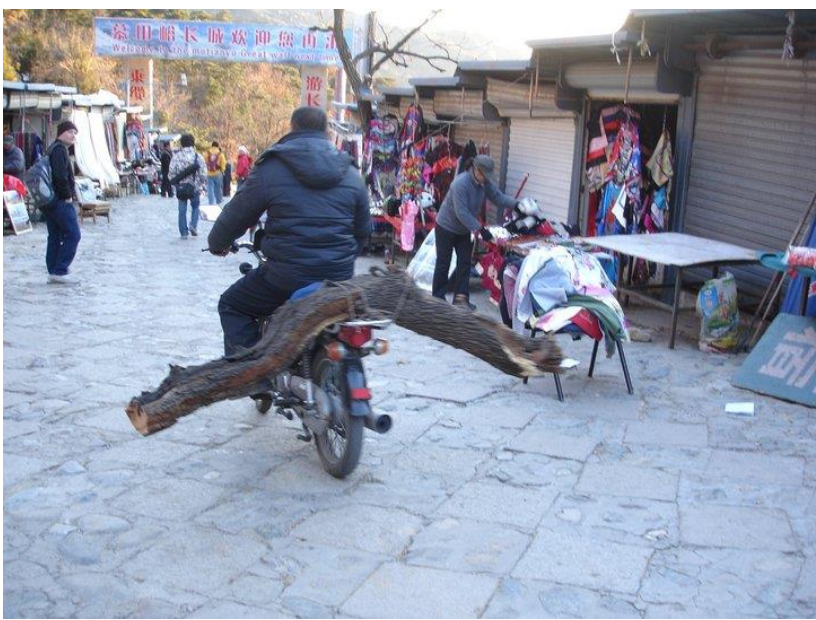

Fig. 2. Visual example of energy-related concepts and terms, used for classroom discussion.

\subsection{Decision Making Frameworks}

Several decision making frameworks were introduced in the context of developing a sustainable mindset in firstyear engineering students. The first framework practiced as a critical thinking tool was a decision tree, i.e. given a case, students were enabled to determine what the first question to ask regarding sustainability would be, then what the "yes" or "no" paths would be, resulting in subsequent questions.

In addition, the various criteria for making ethical choices, including:

- Utilitarian criterion: A decision focused on outcomes or consequences that emphasize the greatest good for the greatest number of people,

- Rights criterion: Decisions consistent with fundamental liberties and privileges as set forth in documents like the Canadian Charter of Rights and Freedoms,

- Justice criterion: Decisions that impose and enforce rules fairly and impartially so there is an equitable distribution of benefits and costs,

- Care criterion: Decision that expresses care in protecting the special relationships that individuals have with each other,

combined with concepts from organizational behaviour theory, such as the stages of moral development of preconvention, convention, and principled stages, emphasized that the shared objective of implementing sustainability into engineering has many human and technical components [8].

Students were also introduced to what a stakeholder analysis is, i.e. considering those individuals or entities that have influence over a decision, those who will be 
affected, and the level of influence or affectedness when such a decision is made, shown in Fig. 3.

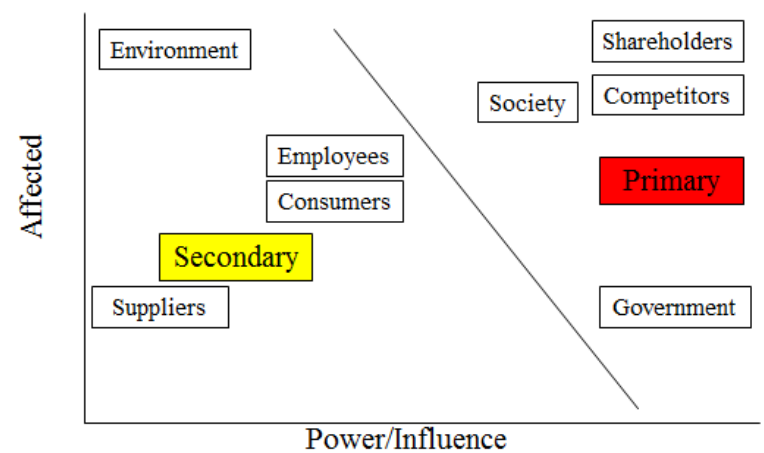

Fig. 3. Stakeholder analysis.

\subsection{Materials Life Cycle Assessment}

A materials life cycle assessment considers the inputs, such as energy, and outputs, such as $\mathrm{CO}_{2}$ emissions, in each step of a material's life, from extraction out of the earth (or its chemical synthesis), to its production or manufacturing, its packaging, transporting and distribution, its storage and use, and finally to its end-oflife. There are several end-of-life potential (EOL) alternatives, including landfill disposal, recycling, reusing, down-cycling, or repurposing. Classroom discussion included several case analyses:

- Drilling in the Alaskan National Wildlife Reserve

- Production of aluminum cans

- Mining of rare earth elements in the United States

- BMW's recycling process

- Landfills of electronic waste

- Boston Dynamics' robots

- Manufacturing of cymbals in Nova Scotia

- Single-use coffee pods

- Autonomous intelligent systems for sense-andavoid

- 3D metal printing

- The Canadarm

- Designing for Accessibility

with each example used for the students to analyze the engineering design or innovation, its inputs and outputs, what stage of the materials life cycle it was in, and whether the technology presented was a sustainable solution [9]. In addition, the concepts of the human development index (HDI) and anthropogenic activities are integrated into the analysis of the life cycle assessment [10].

\section{RESULTS AND DISCUSSION}

For each topic, there was a biweekly assignment for self-reflection, called Check-Ins, as shown in Fig. 4.
For this Check-In, please look at the case of the Arctic National Wildlife Refuge in Alaska. Using the handout from class (attached for your reference here), the links we looked at in class, and referencing any additional information you research:

1. Identify the stakeholders in this case and draw/create a stakeholder analysis, labeling and explaining who your primary and secondary stakeholders are and why.

2. Make a decision tree on how you would arrive at your decision "to drill or not to drill".

3. Use any other frameworks we've discussed, including the Stages of Moral Development and the Four Criteria for Ethical Decision Making to support and arrive at your decision.

4. Clearly state your conclusion/decision based on your analysis at the end of your submission.

5. Then, "vote" for your decision: YES - drill (as supported by your Check-In submission) or NO - do not drill (as supported by your Check-In submission) here: https://goo.gl/forms/link.

Your vote will be anonymous but I will show what the class decided in an upcoming class! Imagine yourself as a decision maker in an engineering / international oil exploration company. I expect you to spend an hour on this check-in, which does not include the reflection and preparation for the final submission next Thursday.

Fig. 4. Example check-in.

Fig. 5 shows the results of this Check-In, with the professor emphasizing that "No, do not drill" is not necessarily the only right answer, but that a "Yes, drill" with well-developed supporting analysis is just as valid and important for critical thinking about sustainability.

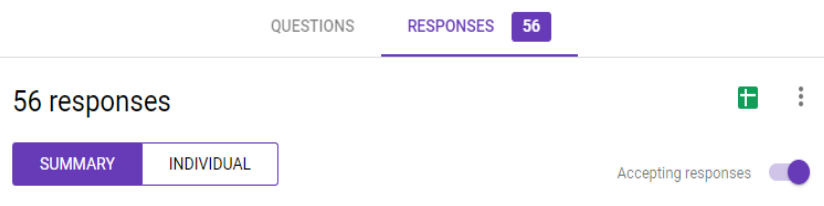

My decision regarding ANWR, based on my stakeholder analysis and application of several frameworks for ethical decision making, is to:
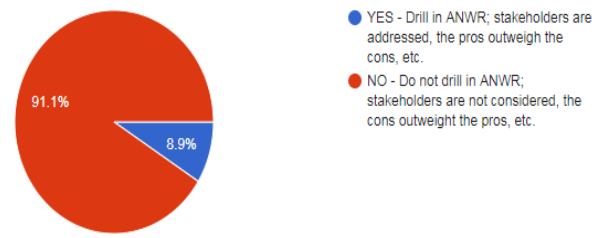

Fig. 5. Results of critical thinking for developing a sustainability mindset: Yes $91.1 \%$ drill in ANWR and No $8.9 \%$ do not drill in ANWR.

\subsection{Living Lab: Materials End-of-Life Potential}

There were two team-based projects, the first one of which named a "living lab," referring to the students as being part of an active experiment and personal observation. Fig. 6 shows the details of Assignment \#1. 
Assignment \#1: Living Lab on Plastics and Their End of Life Potential

- In your lab groups, collect your plastic waste over a period of one week (7 days).

- Meet together to inventory your plastics collection, categorizing them by:

○ Product or category, i.e. health care, packaging, cosmetics, caps, bottles, etc.

- Polymer material

- Show your group's collection using photos of the plastics you use.

- Measure the total weight (grams) of the plastic waste you have accumulated over one week.

- Identify the options for each item in your plastics collection for end-of-life. Refer to the tables in the Lecture Notes, the resin code numbers, and any other resources you find. Note all resources should be properly reference.

- Consider what percentage $(r)$ can be recycled from your collection and attempt to approximate or calculate the EoL Potential credit, in terms of Energy and $\mathrm{CO}_{2}$ footprint.

- 7 days for Part I

- 7 days for Part II

- Use the rest of the time to analyze and evaluate your results with your lab group and prepare the memo for submission

\section{THE WRITE-UP: A MEMORANDUM}

The write-up for this Living Lab assignment will be a technical memorandum. A memorandum is a common form of written communication in the professional environment that facilitates communication in a clear and concise manner. It is characterized by a detailed and succinct description of a subject (restricted to 1,400 words or less, not counting key figures or charts in a short appendices), typically written to inform a decision-maker or a person of authority in the organization. A memorandum includes three sections: an introduction, a body, and a conclusion.

\section{Part I}

- Visual depiction of your inventory of plastics collected, i.e. chart, graph, table, categorized by product and polymer type.

- Images of your plastic collection (included in the Appendices) and referenced in the text of the memo.

- Analysis and evaluation of your plastics collection: what waste was generated, amounts, linking to your group's habits, etc.

- Discussion on the End-of-Life Potential options for your plastics collection and why.

- Estimation of the percentage recyclable and your attempt to calculate the EoL Potential credit, in terms of Energy and $\mathrm{CO}_{2}$ footprint, explaining your assumptions and calculations.

Part II

- Discuss as a group what you can collectively do to reduce your plastic waste collection.
- Decide on three action items and now track/collect your plastics (instead of throwing them out) for the next seven (7) days.

- Again, create a visual depiction of your inventory of plastics collected, i.e. chart, graph, table, categorized by product and polymer type. What was the change? Show this change on your visual.

- Images of your new plastic collection (included in the Appendices) and referenced in the text of the memo.

- Analysis and evaluation of your new plastics collection and the effect of your three action items on the items' End-of-Life-Potential, your carbon footprint, and the Energy ratio.

Fig.6. Assignment on Monitoring Plastic Use.

Figs. 7 and 8 show student results from Week 1 and Week 2 , where this student's plastic waste was reduced by $78 \%$.

\begin{tabular}{|c|c|c|c|c|}
\hline Item & Material & \# & EOL & Weight \\
\hline $\begin{array}{l}\text { Tim Horton's } \\
\text { Water bottle }\end{array}$ & PE-HD & 1 & $\begin{array}{l}\text { Resin code } 2, \\
\text { can be recycled }\end{array}$ & $11.0 \mathrm{~g}$ \\
\hline $\begin{array}{l}\text { Mechanical } \\
\text { pencil } \\
\text { packaging }\end{array}$ & LDPE & 2 & $\begin{array}{l}\text { Resin code } 4, \\
\text { can be recycled }\end{array}$ & $11.6 \mathrm{~g}$ \\
\hline $\begin{array}{l}\text { ADL } \\
\text { chocolate } \\
\text { milk bottle }\end{array}$ & HDPE & 2 & $\begin{array}{l}\text { Resin code } 2, \\
\text { can be recycled }\end{array}$ & $60.0 \mathrm{~g}$ \\
\hline $\begin{array}{l}\text { Sobeys to go } \\
\text { chicken } \\
\text { package } \\
\text { bottom }\end{array}$ & $\mathrm{PP}$ & 1 & $\begin{array}{l}\text { Resin code } 5, \\
\text { can be recycled }\end{array}$ & $29.6 \mathrm{~g}$ \\
\hline $\begin{array}{l}\text { Sobeys to go } \\
\text { chicken } \\
\text { package lid }\end{array}$ & PS & 1 & $\begin{array}{l}\text { Resin code } 6, \\
\text { cannot be } \\
\text { recycled }\end{array}$ & $15.8 \mathrm{~g}$ \\
\hline $\begin{array}{l}\text { Loreal } \\
\text { shampoo } \\
\text { bottle }\end{array}$ & PETE & 1 & $\begin{array}{l}\text { Resin code } 1, \\
\text { can be recycled }\end{array}$ & $62.4 \mathrm{~g}$ \\
\hline $\begin{array}{l}\text { Tim Horton's } \\
\text { coffee lid }\end{array}$ & PS & 1 & $\begin{array}{l}\text { Resin code } 6, \\
\text { cannot be } \\
\text { recycled }\end{array}$ & $2.8 \mathrm{~g}$ \\
\hline Grocery bags & PE-HD & 2 & $\begin{array}{l}\text { Resin code } 2, \\
\text { can be recycled }\end{array}$ & $13.5 \mathrm{~g}$ \\
\hline $\begin{array}{l}\text { Reese's cup } \\
\text { packaging }\end{array}$ & LDPE & 1 & $\begin{array}{l}\text { Resin code } 4, \\
\text { can recycle }\end{array}$ & $1.0 \mathrm{~g}$ \\
\hline & & & TOTAL & $207.7 \mathrm{~g}$ \\
\hline \multicolumn{5}{|c|}{$\begin{array}{l}\text { Group Goals for Week 2: } \\
\text { - Use reusable containers as opposed to Ziploc bags. } \\
\text { - Use reusable mugs at coffee shops rather than } \\
\text { disposable cups and lids. } \\
\text { - Refrain from using single use grocery bags, take } \\
\text { reusable bags instead. }\end{array}$} \\
\hline
\end{tabular}

Fig.7. Example of Plastic Use Week 1.

\begin{tabular}{|l|l|l|l|l|}
\hline Item & Material & $\#$ & EOL & Weight \\
\hline Bread bag & LDPE & 1 & $\begin{array}{l}\text { Resin code 4, } \\
\text { can recycle }\end{array}$ & $6.8 \mathrm{~g}$ \\
\hline $\begin{array}{l}\text { Granola } \\
\text { bar } \\
\text { wrapper }\end{array}$ & LDPE & 2 & $\begin{array}{l}\text { Resin code 4, } \\
\text { can recycle }\end{array}$ & $1.2 \mathrm{~g}$ \\
\hline
\end{tabular}




\begin{tabular}{|l|l|l|l|l|}
\hline $\begin{array}{l}\text { Saran } \\
\text { wrap }\end{array}$ & PVC & 2 & $\begin{array}{l}\text { Resin code 3, } \\
\text { can recycle }\end{array}$ & $7.8 \mathrm{~g}$ \\
\hline $\begin{array}{l}\text { Tostitos } \\
\text { bag }\end{array}$ & LDPE-PP & 1 & $\begin{array}{l}\text { Resin code 4 } \\
\text { and 5, can be } \\
\text { recycled }\end{array}$ & $8.7 \mathrm{~g}$ \\
\hline $\begin{array}{l}\text { Ziploc } \\
\text { bags }\end{array}$ & LDPE & 2 & $\begin{array}{l}\text { Resin code 4, } \\
\text { can recycle }\end{array}$ & $5.6 \mathrm{~g}$ \\
\hline $\begin{array}{l}\text { Grocery } \\
\text { bag }\end{array}$ & PE-HD & 1 & $\begin{array}{l}\text { Resin code 2, } \\
\text { can recycle }\end{array}$ & $5.8 \mathrm{~g}$ \\
\hline \multicolumn{4}{|c|}{} & \multicolumn{2}{|c|}{ Total } & $45.5 \mathrm{~g}$ \\
\hline $\begin{array}{l}\text { I reduced plastics used but group goals were not all achieved } \\
\text { as I still used Ziploc and one-use grocery bags this week. }\end{array}$ \\
\hline
\end{tabular}

Fig.8. Example of Plastic Use Week 2.

\subsection{Materials Life Cycle Analysis}

The second team-based assignment was to conduct a materials life cycle assessment of a manufactured product. One group explored the life cycle of an egg carton and considered the material for the egg carton, the manufacturing process, the energy source for production, and the transportation method. The assignment also asked students had to make three unique changes to the materials life cycle; in this example, as shown in Fig. 9, the students considered air drying the egg cartons instead of using electricity, using renewable energy sources for production, and changing the distance that the egg cartons had to be transported.

The purpose of this memorandum is to evaluate
and assess the life cycle of an egg carton. Using
GaBi software, the environmental impact of
manufacturing and transporting egg cartons will
be quantitatively described. The production
process has 3 main components: creating pulp,
molding the pulp into cartons, and drying the
formed molds. Once the cartons have been dried,
they can be packaged and transported to the
user. They are then either recycled for future
pulp creation, or they are disposed of, thus
completing the life cycle. Through our analysis
using the GaBi software, we have found that the
creation of $1 \mathrm{~kg}$ of egg cartons emitted $1.55 \mathrm{~kg}$ of
CO $\mathrm{O}_{2}$ into the environment. After experimenting
with changes to the types of energy used, we
found that using renewable energy sources such
as solar energy was the most effective change.
The emitted CO ${ }_{2}$ was reduced to 0.74lkg, less
than half of the original carbon footprint.

Fig.9. Example of Life Cycle Analysis of an Egg Carton

\subsection{Developing a Sustainability Mindset}

Students were asked to define what sustainability means during the first week of the course and in the final week of the semester. A content analysis of each of the submitted definitions indicated that the top three key words shifted from being (1) "long-term" or "long- standing", (2) "resources", and (3) "future", to the top three key words being related to (1) "impact", (2) "global" or "the world", and (3) "people" or "others". The final question was posed as an interaction, i.e. "how would you describe 'sustainability in engineering design' to a high school student at your local school or to your 80year old grandfather?" This change correlates with the progression of topics covered in the course:

- Climate / Environment / Oceans

- Plastics

- Buy Local

- Energy and Electricity

- Human Rights and Freedoms / Sustainability Goals

- Philosophy of Technology

- Stakeholder Analysis and Sustainability in Ethics

- Life Cycle Assessment

- $\quad$ Sustainability in Engineering Design

- Robotics

- 3D Printing and Additive Manufacturing

- Accessibility

- Materials for Sustainability and Sustainable Materials

The foundations for a sustainability mindset in our firstyear engineering students were set, through various hands-on, experiential learning activities:

- Assignment on Plastic Waste

- Assignment on Sustainability for UPEI

- Lab on Basic Engineering Experimentation

- Lab on Life Cycle Assessment Using Gabi Software

- Guest Speakers from Campus Facilities, Wind Energy, and Sustainable Engineering Research

- $\quad$ Check-Ins

It can also be added that the course attempted to set a foundation of a sustainable attitude for success in our first-year engineering students, encouraging participation, discipline, quality of work, self-growth and reflection, and communication skills.

\section{CONCLUSION}

At the end of the semester, an acronym was derived to summarize what a sustainability mindset entails:

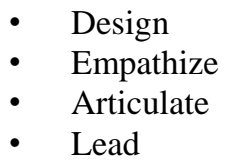

D.E.A.L. is a play on the "reluctant" approach that some currently appear to take towards sustainability and environmental stewardship. Instead, D.E.A.L. means to serve as a reminder that future engineers should incorporate a mindset towards sustainable development in their problem solving and engineering design. This purposeful D.E.A.L. approach includes empathy of the 
persons as well skills for the problem to be solved, articulation of the critical needs at hand regarding energy and the environment, and leadership as both a global citizen and a future engineer.

The concepts, issues, and themes of Sustainability in Engineering Design are introduced and developed in a first-year engineering course. Students reflect upon, apply, and analyze many examples and aspects of sustainability. As a result, an understanding of Sustainability is established such that students are able to design for, articulate, quantify, and lead in Sustainability and build upon these concepts in later courses in Sustainable Design Engineering program at UPEI.

\section{References}

[1] An Inconvenient Truth: A Global Warning. Dir. Davis Guggenheim. Perf. Al Gore. Paramount, 2006.

[2] Susie East, Four Years Trash,, One Jar...Zero Waste, CNN, July 6, 2016, https://www.cnn.com/2016/07/04/us/laurensinger-zero-waste-blogger-plastic/index.html. Accessed September to November 2018.

[3] Sherry Turkle, Connected, but Alone?, TedTalk, February 2012, https://www.ted.com/talks/sherry_turkle_alone_t ogether?language=en. Accessed September to November 2018.

[4] Parmy Olson, Amazon Just Unveiled Its Plan for Whole Foods to Make the 'Last Mile' the First Mile, Forbes, February 8, 2018, https://www.forbes.com/sites/parmyolson/2018/0 2/08/amazon-wholefoods-delivery-grocery-lastmile/\#6e9d56fe1300. Accessed September to November 2018.

[5] Michael E. Porter and Mark R. Kramer, "Strategy and Society: The Link Between Competitive Advantage and Corporate Social Responsibility," Harvard Business Review, 84, no. 12, pp. 78-79, 2006.

[6] Sheila Dang, China's TCL Launches High-End BlackBerry Smartphone in U.S., Reuters, June 7, 2018, https://www.reuters.com/article/usblackberry-smartphone/chinas-tcl-launches-highend-blackberry-smartphone-in-u-s-

idUSKCN1J32DZ. Accessed September to November 2018.

[7] United States Energy Information Administration, https://www.eia.gov/tools/faqs/faq.php?id=87\&t $=1$. Accessed September to November 2018 .

[8] Lawrence Kohlberg, "Moral Stages and Moralization: The Cognitive-Developmental Approach," Moral Development and Behaviour: Theory, Research, and Social Issues, ed. T. Lickona (New York: Holt, Rinehart and Winston), pp. 34-35, 1976.

[9] Guido Bugmann, Rachel Burcin, Mel Siegel, “ $A$ Role for Robotics in Sustainable Development", Proc. of IEEE Africon '2011, 13-15 Sept., Livingstone, Zambia, 2011.

[10] Bradley Striebig, Adebayo Ogundipe, Maria Papadakis, Engineering Applications in Sustainable Design and Development, Cengage Learning, Boston, MA, 2016. 